\title{
Intracytoplasmic Inclusion Bodies Associated with Vesicular, Ulcerative and Necrotizing Lesions of the Digestive Mucosa of a Roedeer (Capreolus Capreolus L.) and a Moose (Alces Alces L.)
}

\author{
By R. Feinstein, C. Rehbinder, E. Rivera, T. Nikkilä and M. Steen
}

\begin{abstract}
Feinstein, R., C. Rehbinder, E. Rivera, T. Nikkilă and M. Steen: Intracytoplasmic inclusion bodies associated with vesicular, ulcerative and necrotizing lesions of the digestive mucosa of a roedeer (Capreolus capreolus L.) and a moose (Alces alces L.) Acta vet. scand., 1987, 28, 197-200. - At post-mortem examination of a roedeer and a moose, ulcerative and necrotizing lesions were observed in the digestive mucosa.

Both animals were serologically positive for Bovine Viral Diarrhea Virus antibodies. Histological examination revealed intra- and intercellular oedema in stratum germinativum and spinosum, formation of vesicles and ulcers, and intracytoplasmic inclusion bodies in numerous epithelial cells of mainly stratum germinativum.

Electronmicroscopy confirmed the histological findings and demonstrated inclusion bodies containing a granular electron dense material encircled by a singlelayer membrane. Virus particles were not found.
\end{abstract}

ulcerations; intracytoplasmic inclusion bodies; Bovine Viral Diarrhea.

\section{Introduction}

An emaciated female roedeer and an emaciated female moose found dead, were submitted for routine post-mortem examination at the National Veterinary Institute, Uppsala, Sweden. At necropsy, both animals presented numerous erosive, ulcerative and necrotizing lesions of the digestive mucosa. Histological and electronmicroscopial studies were performed in order to investigate the nature of the lesions.

\section{Material and methods}

Histology: Tissues were fixed in $10 \%$ buffered formaline, enbedded in paraffin, cut 4 micron thick-sections and stained with hematoxylin and eosin.

Electronmicroscopy: Selected areas of oral epithelium were cut from paraffin blocks, and processed as described by (Rehbinder et al. 1985).

Serological test for BVDV-antibodies: Heart blood was collected during necropsy. A Conventional serum neutralization test was performed in a microtiter system.

\section{Results}

Necropsy findings

The roedeer was 8 years old and the moose 6 years old (age based on dental wear). Both 
were female and presented severe emaciation. Autolysis was moderate. The lesions at the digestive mucosa were very similar in both animals. Numerous erosions, ulcers and necrotizing lesions were observed in the oral mucosa. The majority of these were located on the posterior part of the dorsal surface of the tongue and in the oropharynx, but infrequently also in the gingiva around the upper premolars. All lesions were irregularly rounded, 1 to $4 \mathrm{~mm}$ in diameter, with elevated margins and a smooth bright red bottom (Fig. 1). The moose also presented a large number of linear ulcerations in the oesophageal mucosa, and some erosions on the ruminal pillars and in the abomasal mucosa. The spleen was markedly atrophied.

\section{Histological findings}

The oral mucosa revealed changes in the epithelium consisting of intra- and intercellular oedema and degeneration and necrosis in stratum germinativum and spinosum. Vesicles, that were not detected at macroscopical examination, appeared as circumscribed areas nor raised above the level of adjacent epithelium (Fig. 2). They were filled with slightly eosinophilic fluid. Sloughing of epithelium apparently lead to erosions and ulcerations. Inflammatory infiltration consisting mainly of neutrophils was present only where necrosis of epithelium affected the basal layer. Ulcers frequently showed bacterial colonies and mixed leukocytic infiltration. Vessels in the lamina propia were devoid of inflammatory changes. Numerous cells in stratum germinativum and spinosum contained intracytoplasmic, slightly basophilic, inclusion bodies (Fig. 3). In general, cells presented one inclusion body, but, in occasional cells, 2 or 3 could be seen. Inclusion bodies were round, 2 to 10 microns in diameter (Fig. 4). They were frequently sur- rounded by a clear halo, and in some cells a vacuole was present instead of the inclusion body.

\section{Electronmicroscopical studies}

Electronmicroscopy confirmed the histological findings. Virus particles were not found. Inclusion bodies were enclosed in a cytoplasmic vacuole and consisted of electron dense granular material surrounded by a single layer membrane (Fig. 5). Often vacuoles were partly empty, the limiting membrane surrounding an empty space, or containing varying amounts of a granular material. Frequently, the membrane of the inclusion body and that of the vacuole run parallel in close apposition creating the impression of a double membrane, but fluid accumulation around the inclusion body often separated the 2 membranes. Constant features in the epithelium were clumping of tonofilaments and intra- and intercellular oedema (Fig. 6).

\section{Serological test for $B V D V$-antibodies}

Both animals were positive for BVDV-antibodies.

\section{Discussion}

Inclusion bodies are commonly associated with virus infections (Watrach 1972). Our electronmicroscopical study revealed inclusion bodies containing electron dense granular material encircled by a single membrane. Virus particles, however, were not observed. Yet, a viral etiology can not be excluded as inclusion bodies do not always contain virus particles (Okada \& Fujumoto 1975). Inclusion bodies are very prominent in poxvirus infections (Fenner \& Burnet 1957, Fenner 1979). Bovine papular stomatitis, a usually mild disease produced by a poxvirus could be associated with erosion and ulceration of the digestive mucosa, and intracytoplasmic 
R. Feinstein, C. Rehbinder, E. Rivera, T. Nikkilä and M. Steen: Intracytoplasmic inclusion bodies associated with vesicular, ulcerative and necrotizing lesions of the digestive mucosa of a roedeer (Capreolus capreolus L.) and a moose (Alces alces L.).

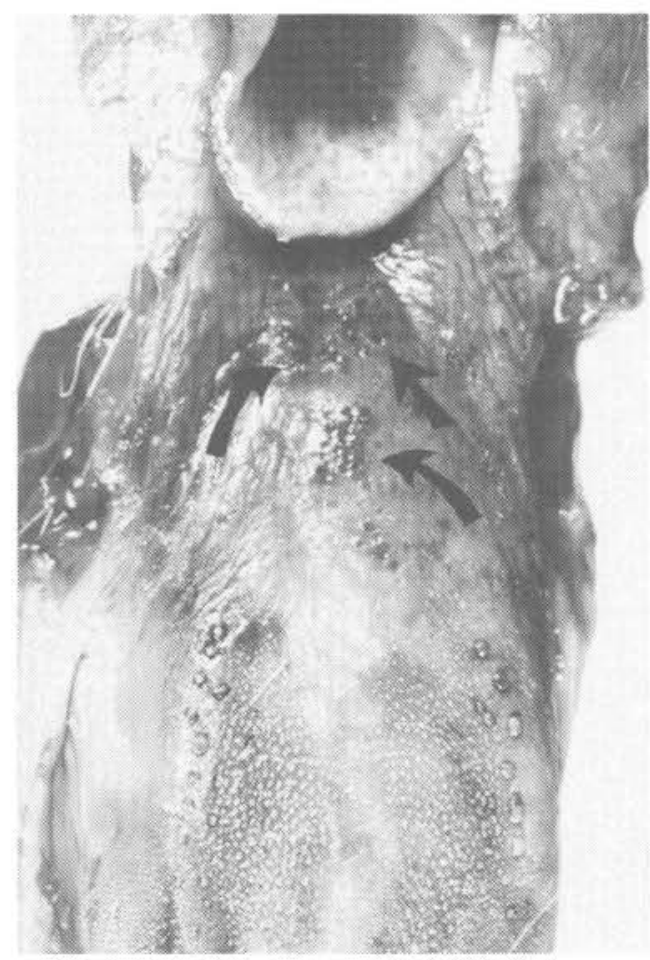

Figure 1. Roedeer. Ulcerations in the mucosa of the oropharynx and of the posterior part of the dorsal surface of the tongue (arrows).

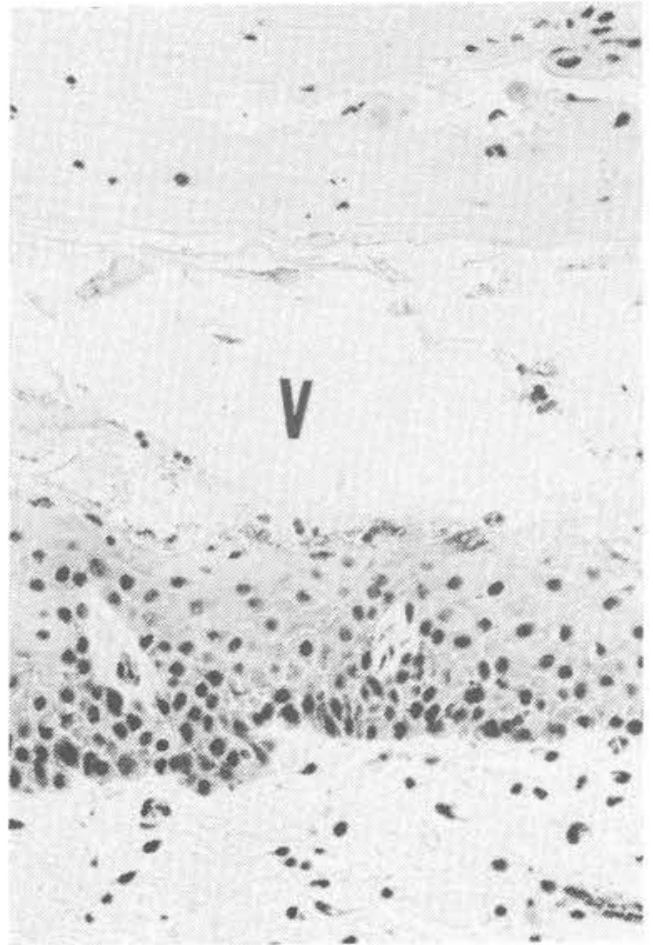

Figure 2. Moose. Vesicle in the buccal epithelium (v) and mild leukocytic infiltration of lamina propia $\times 40$. 


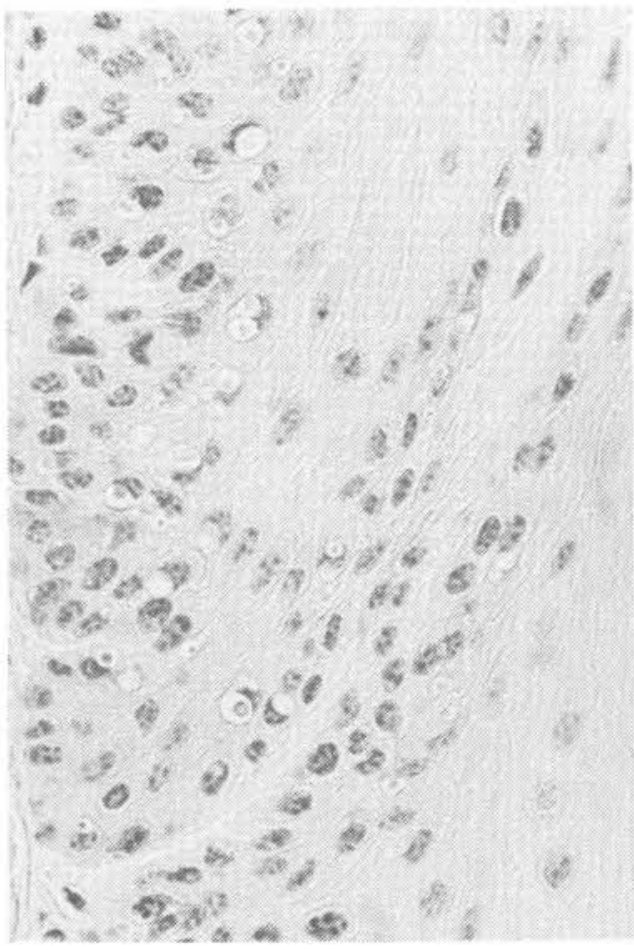

Figure 3. Moose. Buccal epithelium with numerous intracytoplasmic inclusion bodies in statum germinativum and spinosum $\times 110$.

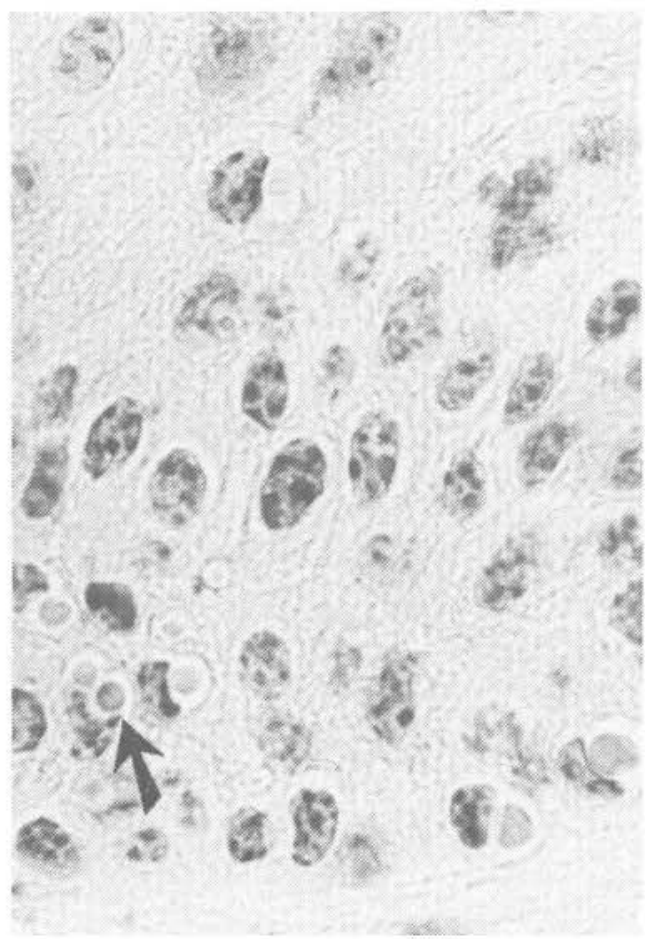

Figure 4. Roedeer. Buccal epithelium with intracytoplasmic inclusion bodies in stratum germinativum and spinosum. A cell containing 2 inclusion bodies is marked (arrow). Nuclei are compressed to a crescent shape $\times 450$. 


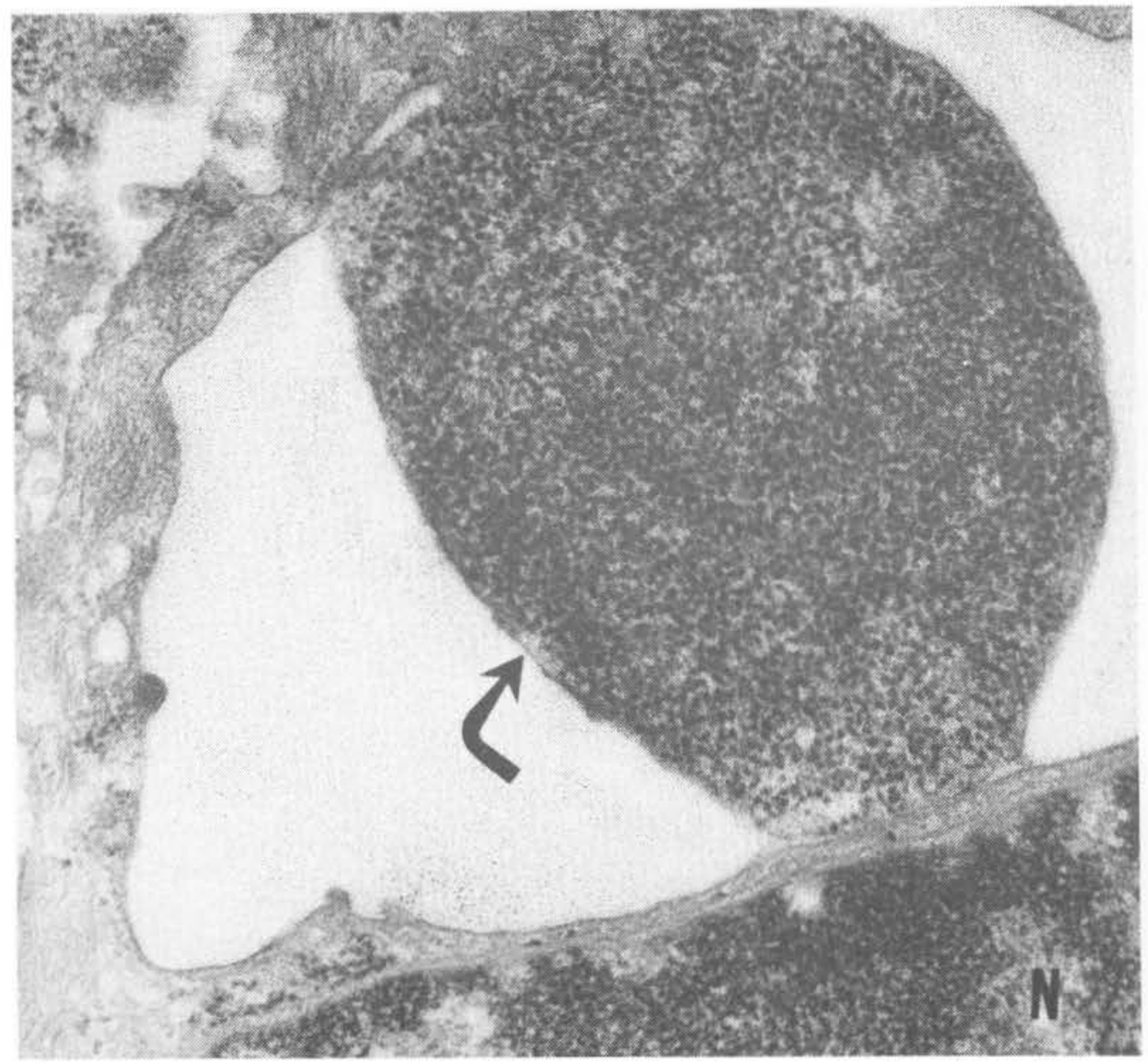

Figure 5. Roedeer. Buccal epithelium. An incłusion body (arrow) located close to the nucleus $(\mathrm{N})$ shows a single membrane enclosing electrodense granular material $\times 25000$. 


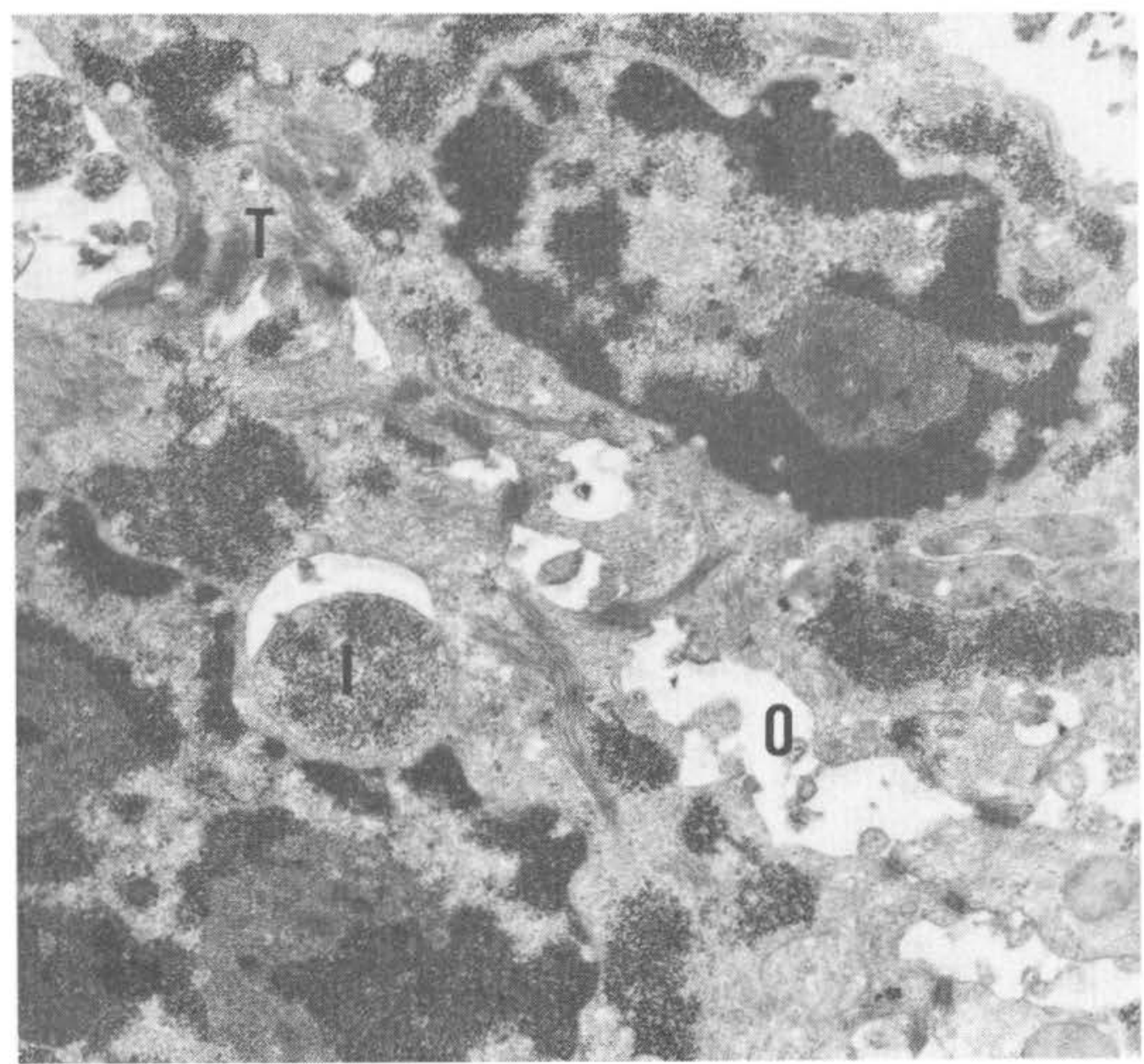

Figure 6. Buccal epithelium showing intercellular oedema (0) and clumping of tonofilaments (T). An inclusion body (1) is located close to a nucleus $\times 3200$. 
inclusion bodies in the epithelium (Griesemar \& Cole 1960, 1961). The disease could be agravated by stress and be quite severe in debilitated animals (Crandel \& Gosser 1974). The inclusion bodies were described as eosinophilic and basophilic (Okada \& Fujumoto 1975). The basophilic ones contained numerous viral particles readily observed in electronmicroscopy. Eosinophilic inclusion bodies, however, did not contain virus but a homogenous opaque matrix different from the granular material observed in this investigation.

Contagious ecthyma (orf or contagious pustular dermatitis) is a poxviral disease associated with intracytoplasmic inclusion bodies in the alimentary epithelium, but the macro- and microscopical changes are different from those found in this investigation (Jubb et al. 1985). The lesions of vesicular stomatitis, a disease produced by a rhabdovirus, could be compatible with the ones we observed, but inclusion bodies do not occur (Karstad \& Hanson 1957, Jubb et al. 1985). BVD is apparently a prevalent disease among wild cervidae, as indicated by different surveys (Romvary 1965, Thorsen \& Henderson 1971, McMartin et al. 1977, Lawman et al. 1978, Elazhary et al. 1979, Couvillion et al. 1980, Elazhary et al. 1981, Weber et al. 1982, Doyle \& Heuschele 2983). In addition, it is considered that over 60 per cent of all adult Swedish cattle has passed a BVDV-infection. hence the finding of BVDV-antibodies is not surprising and, more over, suggests that the lesions were not produced by BVDV (Alenius \& Jacobsson 1984). Furthermore the histopathological picture differed from that of a BVV infection in which more of oedema, cell shrinkage, acidophilic cytoplasm and karyo-pyknosis is seen (Hansen et al. 1962). Hansen et al. also observed intracytoplasmic inclusions. These were, however, irregularly sha- ped, located in the stratum granulosum and apparently of keratogenic origin.

Lesions and inclusion bodies similar to those described in this investigation were reported in reindeer (Rangifer tarandus L.) from herds known to be negative for BVD. A possible viral etiology was then suggested but not proved (Rehbinder et al. 1985).

During the operation of this report the National Veterinary Institute have received additional moose and roedeer displaying similar lesions and revealing inclusion bodies. Some of these animals were positive for BVDVantibodies, but some, 2 out of 5 roedeer and 7 out of 15 moose, were negative both for BVD-virus and BVDV-antibodies. Study of this material is in progress.

\section{References}

Alenius $S$, Jacobsson $S$ - $O$ : Infektioner med bovint virusdiarrevirus hos nötkreatur. (Infections with bovine virus diarrhoeavirus in cattle). Svensk Veterinärtidning 1984, 36, 725-731.

Couvillion CE, Jenney EW, Pearson JE, Coker $M E$ : Survey for antibodies to viruses of Bovine Virus Diarrhoea, Bluetongue, and Epizootic Hemorrhagic Disease in hunter-killed mule deer in New Mexico. J. Amer. vet. med. Assoc. 1980, 177, 790-791.

Crandell RA, Gosser HS: Ulcerative esophagitis associated with poxvirus infection in a calf. $\mathrm{J}$. Amer. vet. med. Assoc. 1974, 165, 282-283.

Doyle, LG, Heuschle WP: Bovine viral diarrhoea virus infection in captive exotic ruminants. J. Amer. vet. med. Assoc. 1983, 173, 1257-1259.

Elazhary MASY, Roy RS, Frechette JL: Serological evidence of IBR and BVD infection in caribou (Rangifer Tarandus) Vet. Rec. 1979, 105, 336.

Fenner F, Burnet FM: A short description of the poxvirus group (vaccinia and related viruses). Virology 1957, 4, 305-314.

Fenner F: Portraits of viruses. The poxiviruses. Intervirology 1979, 11, 137-157. 
Griesemer RA, Cole CR: Bovine Papular Stomatitis. 1. Recognition in the United States. J. Amer. vet. med. Assoc. 1960, 137, 404-410.

Griesemer RA, Cole CR: Bovine Papular Stomatis. III. Histopathology. Amer. J. vet. Res. 1961, 22, 482-486.

Hansen, H-J, Ronéus O, Dinter Z: Untersuchungen über Mucosal Disease II. Pathologische Anatomie der Krankheit in Vergleich mit dem cytopathogenen Effect des Virus diarrhoae auf Gewebekultur. (Studies on Mucosal Disease II. The pathology of the disease in comparison with the cytopathogenic effect of bovine virus diarrhoea virus on tissue culture). Zbl. Vet. Med. 1962, 9, 854-864.

Jubb KVF, Kennedy PC, Palmer N: Pathology of Domestic Animals. Vol. 2. Third edition. Academic Press, Inc. 1985, p. 95-100.

Karstad L, Hanson RP: Vesicular stomatitis in deer. Amer. J. vet. res. 1957, 162-16.

Lawman JP, Evans D, Gibbs EJP, McDiarmid A, Rowe $L$ : A preliminary survey of British deer for antibody to some virus diseases of farm animals. Brit. vet. J. 1978, 134, 85-91.

McMartin DA, Snodgrass DR, Corrigall W: Bovine virus diarrhoea antibody in a scottish red deer. Vet. Rec. 1977, 100, 85-91.

Okada K, Fujumoto $V$ : The fine structure of cytoplasmic inclusions and virus particles of bovine papular stomatitis. Jap. J. vet. Res. 1975, $23,33-40$.

Rehbinder C, Nordkvist M, Moreno JW, Siddiqui I: A suspected virus infection of the oral mucosa in Swedish reindeer (Rangifer Tarandus L). Rangifer 1985, 5, 22-31.
Romvary J: Incidence of virus diarrhoea among roes. Acta Vet. Acad. Sci. Hung. 1965, 15, 451-455.

Thorsen J, Henderson JP: Survey for antibodies to infectious bovine rhinotracheitis (IBR), bovine virus diarrhoea (BVD) and parainfluenza 3 (PI3) in moose sera. J. Wildlife Dis. 1971, 7, 93-95.

Watrach AM: The ultrastructural basis of cell injury in viral infections. Adv. Vet. Sci. comp. Med. 1972, 16, 175-199.

Weber KH, Hurter K-P, Commichau C: Über das vorkommen des virusdiarrhoea/mucosal disease - Virus bei cerviden in Rheinland. (The occurrence of Virus diarrhoea - mucosal disease. Virus in cervidae in Rheinland). Pfalz Dtsch. Tierarzl. Wschr. 1982, 89, 1-3.

\section{Sammanfattning \\ Intracytoplasmatiska inklusionskroppar associe- rade med vesikulära, ulcerativa och nekrotise- rande lesioner $i$ digestionskanalens slemhinnor hos et rådjur (Capreolus capreolus L) och en älg (Alces alces L). \\ Vid obduktion av ett rådjur och en älg påvisades ulcerativa och nekrotiserande skador i digestions- kanalens slemhinnor. Både djuren hade antikrop- par emot Bovin Virus Diarre. Histologiskt påvisa- des inter- och intracellulärt ödem i stratum germi- nativum och spinosum, vesikelbildning och ulce- rationer samt intracytoplasmatiska inklusions- kroppar huvudsakligen i stratum germinativum. Elektronmikroskopi bekräftade de histologiska fynden och inklusionskroppar innehållande ett kornigt elektrontätt material, omslutet av ett enskiktat membran. Virus partiklar kunde där- emot ej påvisas.}

(Received January 16, 1987).

Reprints may be requested from: R. E. Feinstein, National Veterinary Institute, S-750 07 Uppsala, Sweden. 